\title{
Morale, Productivity and Sustainable Industrial Development in Nigeria
}

\author{
Ejike C. OKOROAFOR $^{1} \quad$ E. B. J. IHERIOHANMA ${ }^{2 *}$ \\ 1.Department of Social Sciences, Federal Polytechnic, Nekede, Owerri Imo State, Nigeria \\ 2.Directorate of General Studies, Federal University of Technology, Owerri Imo State, Nigeria
}

\begin{abstract}
This paper is an analytical discourse on the interface and relationship between morale and productivity and how these have impactful influence on sustainable industrial development in Nigeria. Nigeria is a developing economy that direly needs a strong root and drive for productivity and economic development. This may not be feasible except if the drivers of the economy, particularly the human factor in the production process are not appropriately motivated to energize their morale. This paper that dwelt more on library and secondary sources of materials identified that morale and productivity, though related to each other in many facets, are at the lowest ebbs in Nigeria to essentially drive sustainable industrial development akin to competitive global integrated market economy. It also observed, among others, that certain government truncated policies and poor economic environment within which the human element as factor of production do their work challenge the morale of the operators of the economy. It therefore, recommended, among others, that government policies and work environment should be employees friendly in order to adequately energize them for global practices and to ensure the steady forward movement and progression towards sustainable industrial development in Nigeria.
\end{abstract}

Keywords: Morale, Productivity, Sustainable industrial development, Government policies.

DOI: $10.7176 / \mathrm{DCS} / 10-8-03$

Publication date: August $31^{\text {st }} 2020$

\section{Introduction}

This is a discourse on the interface and correlation between the dual phenomena of morale and productivity and how they influence and positively impact on sustainable industrial development in Nigeria. We are living in a world where we engage in daily activities while being confronted with uncanny environment that affect our capacity to grow and develop in many ways, particularly economically. Our actions or inactions are influenced daily by morale. To produce goods and services is one of the major and common human activities that portend immense implications and benefits to individuals and society. Our needs, interests, values, and particularly morale stand out as factors that influence and often drive our zeal and quest to produce both for subsistence and commercial purposes. Morale and productivity are therefore, related to each other from many perspectives but particularly from the standpoint of the need to do what is not only necessary or essential but also morally justifiable and meaningful to the existence of man and society.

The place of morale in human activities and affairs is quite significant and constructive in meanings and effects; its import extends to every sphere of human exploits and endeavours. It influences human beings in many ramifications and varying degrees. Morale has a lot to do with the level of utilization of human potentials, resources and materials. Morale plays a major role in everyday activities of individuals and even up to the wide scale human interactions/networks and in organizations involved in the production of goods and services (Ogunde, 2013). On the other hand, productivity is a fundamental and very important phenomenon that affects and reflects on the growth and status of industries and work organizations. It tends to influence the way industries grow and develop as well as how they are seen and rated in society. In fact, productivity affects the status and overall development of industries and by so doing influences workers, work organizations, nations and the global economy. Productivity is a critical factor for social and economic development of any economy, nation or society. It is fundamental for industries to grow, expand and satisfy producers and consumers in any given society or economy (Onosode, 2013). Morale can positively influence and empower increased productivity overtime, which will in turn, bring about sustainable productivity. Since productivity is said to be fundamental and instrumental to industrial growth, it can be argued that sustained increase in productivity can also lead to sustained industrial development. This is because productive individuals and organizations make such individuals and organizations (industries) to expand their productivity level or capacity and when this continues and progresses over time, to the benefit of the present without compromising that of the future generations, it is said to be sustainable. It is pursuant to the need to clearly identify the role morale plays in empowering human productivity for sustainable development of industries in Nigeria that necessitated this exposition. In the process, the first part of this investigation dwelt on the introductory background while the second part concentrated on conceptual clarification of the underlying phenomena under discourse. The third part underscores the interface and correlations these concepts have with each other. The forth part analyses the interactions of the concepts in the pursuit of sustainable industrial development in Nigeria taking into consideration the issue of integrated competitive global economy. These form the organization of this study. 
Information here-in is made up of documentary and library sources.

\section{Conceptual Clarification}

\subsection{Meaning and Implications of Morale}

Morale, as a word, has been defined and described in many different but closely related ways that signify its psychosocial meanings and implications in different facets of human activities and experiences (Belson, 2012). Morale, originated in the mid- $18^{\text {th }}$ century from French moral, respelled to preserve the final stress in pronunciation. Morale is defined as the confidence, enthusiasm, and discipline of a person or group at a particular time (Oxford Dictionary, 2020). This definition gives synonyms of morale as “confidence", "enthusiasm", "discipline", and also emphasizes time as a factor that may influence morale of a person or group. In another instance, it is seen as the capacity of a person to repose confidence, maintain belief in an institution, a goal, or even in oneself and others (Belson, 2012). According to Standard Encyclopedic Dictionary (1971), morale is the state of mind with reference to confidence, courage, hope, zeal etc. Morale can be seen as the state of mind of an individual or group of individuals which depicts their level of confidence, courage or zeal in their pursuits or activities, including work, sports, religion, etc.

Morale is a profound concept because of its overwhelming influence on the activities of human beings, particularly in terms of the efforts they can put into whatever they engage in, including the level of confidence and positive feeling that people have, especially people who work together, who belong to the same team, etc. (Longman Dictionary of Contemporary English (2020). It refers to the amount of confidence felt by a person or group of people, especially when in a dangerous or difficult situation. It is the level of satisfaction felt by a person or group of people who work together. High morale helps teamwork and information sharing (Cambridge Dictionary, 2020). From a simple perspective, morale is the amount of confidence and cheerfulness that a group of people have (Collins English Dictionary, 2018). Worthy of note is the fact that most of the definitions of morale are individualistic because it is the state of mind at the individual level, yet it seems to make its greatest impact on human activities due to its effects and influence on group actions or inactions. This is exemplified in the definition of morale as esprit de corps which refers to the capacity of members of a group to pursue and maintain belief in an institution, goal or objective, particularly in the face of opposition or task. It can also be perceived as a generic value judgment of the willpower of a group in the discharge of their duties, responsibilities or tasks in an organization.

Perhaps, Leighton's (1989) definition of morale clearly captures its relationship with human activities and pursuits, particularly in relation to human productivity. It states that morale is the capacity of a group of people to pull together, persistently and consistently, in pursuit of a common purpose. In an organization, employee morale is of high importance given the impact good morale can have on work attitude and productivity. Leighton further cited the influence of morale in an organization using the military as an example, and observes that morale is important in the military because it improves unit cohesion. Without good morale, a force will be more likely to give up or surrender. Morale is usually assessed at a collective, rather than on an individual level. In wartime, civilian morale is also important. Esprit de corps is considered to be an important part of a fighting unit (Leighton, 1989). The above expressions reflect morale as a concept that defines collective consciousness and confidence towards tackling organizational goals and targets. This, in effect, portrays morale as a significant factor in organizations, and because organizations strive to do their best in order to sustain growth and productivity, morale of their employees becomes pivotal and a factor that cannot be compromised if they seek to expand and succeed in the competitive world of organizations.

The working definition of morale in this paper is that it is the capacity with which a person or group of people confronted with a task or situation sustain belief in themselves, an institution or goal to the extent that, persistently it energizes them into fulfillment and realization of the pursuit. The implications of morale cannot be overemphasized because it can have unlimited influence on employee relationships, employee productivity, organizational growth and development. It can have far-reaching effects on outcomes and overall output of individuals and groups that can reflect the status and rating of an organization. Employee morale can affect many facets of a company's business outlook, including productivity, employee commitment and retention and customer service. If employees are not motivated and have low- morale, chances are the company and customers will suffer. Good morale in the workplace can be promoted in several ways to reap the benefits that high morale can offer (McFarlin, 2020). From the meanings and implications of morale, it is inferred that it is a critical and crucial element in human activities, more especially, in the context of human productivity. Morale is the mental and emotional condition of human beings in terms of enthusiasm, spirit and loyalty of an individual or a group with regard to the function(s) or tasks at hand. It cannot be detached from the activities of employees (workers), particularly in relation to work attitude, employee commitment, efficiency and productivity of organizations.

\subsection{The Concept and Issues of Productivity}

The concept of productivity has broad dimensions and implications for individuals, organizations, nations and the 
global economy at large. Productivity relates to the activities and rate at which goods and services are produced. It includes the volume or amount of goods and services produced in relation to the factors of production used and time expended. Organizations often differ in terms of what they produce; while some engage in the production of tangible goods, others are service oriented. Organizations are producing either tangible or intangible materials or services while some produce both goods and services (Obi, Ananti and Onwubiko, 2014). The concept of productivity has always been tied to the relationship that exists between the process of production and the effective utilization of those resources at human disposal. Many of the definitions of productivity are often associated with words such as "value" and "time", because productivity is basically about creating value through the efficient utilization of inputs for greater output within a given time period. There are other elements influencing productivity and efficiency of an organization. Such factors include volume of capital, workload, availability of technology, number of employees and their training, staff motivation, etc.; all these play important roles when considering productivity (Gamelearn, 2020). The following can be included to involve the managerial and leadership styles, conducive work environment, employee morale and commitment, communication and authority structure, promotional and reward systems, and employee job security.

From a literary point of view, productivity refers to the quality, state, or fact of being able to generate, create, enhance, or bring forth goods and services for human usage and consumption. A classic and yet simple definition of productivity is "a way to measure efficiency". In an economic context, productivity is how to measure the output that comes from units of inputs (Robbins, 2018). In consonance with the above definition, productivity is therefore a result of output that exceeds or surpasses a given resource/s input at a point in time. Productivity is a measure of the efficiency of a person, machine, factory, system, etc., in converting inputs into useful outputs. Productivity is computed by dividing average output per period by the total costs incurred or resources (capital, energy, material, personnel) consumed in that period. Productivity is a critical determinant of cost efficiency (Business Dictionary, 2020). It is a term employed to describe output per unit of input. Mathematically, productivity is simply represented as when

\section{$\underline{\text { Output }}=>1$ \\ Input}

The formula above is explained to mean that a productive situation occurs or is achieved when output divided by the resource input is greater than one. In fact, productivity is a classic metric that measures the process of creating goods and services. It is the ratio of the amount of output from a team or organization per unit of input. Conceptually, productivity is a simple metric - measured by simply summing up the number of units of item produced and dividing it by the amount needed to make those units (Metrics, 2016). Productivity is critical because it defines the efficiency of an organization in converting inputs into outputs over time, which in reality creates value and human satisfaction.

From a philosophical dimension, productivity is a philosophy of life, a state of mind. Being efficient means doing, at every moment, what we consciously choose to do and not what we feel we are doing forced by circumstances (Gamelearn, 2020). This definition of productivity connects it to morale which basically relates to the state of mind of employees. Mali (1978) opines that productivity is "the measure of how well resources are brought in organizations and utilized for reaching the highest level of performance with the least expenditure of resources". Akanwa and Ohiri (2003) opine that productivity is the efficient utilization of factors of production in producing goods and services. By implication, if an individual or organization is effective and efficient in the use of resources available, that makes the individual or organization productive. Productivity is commonly defined as a ratio between the volume of output and the volume of inputs. In other words, it measures how efficiently production inputs, such as labour and capital, are being used in an economy to produce a given level of output. Essentially, this paper sees productivity as the efficient and effective utilization of given resources, in time, to produce standard output of goods and services. Productivity not only assumes the state of being productive and efficient but the rate at which goods and services are produced in relation to the ratio of output to input.

Productivity is considered a key source of economic growth and competitiveness and, as such, is the basic statistical information for many international comparisons and country performance assessments. For example, productivity data are used to investigate the impact of product and labour market regulations on economic performance. Productivity growth constitutes an important element for modeling the productive capacity of economies. It also allows analysts to determine capacity utilization, which in turn allows one to gauge the position of economies in the business circle and to forecast economic growth. In addition, production capacity is used to assess demand and inflationary pressures (OECD, 2018).

Productivity is a critical factor for economic and social development of any economy, nation or society. It is fundamental for sustainable industrial development in any economy. For economies to grow, industries and work organizations must first grow and develop. The growth of industries in any nation, including Nigeria, is dependent on productivity improvement or growth. Every society or nation aims to improve its productivity level, especially in this contemporary interconnected, competitive global economic order. Productivity growth, therefore, becomes a challenge to individuals, organizations, industries and nations. Krugman (1994) in his work, The Age of 
Diminishing Expectations, as cited in OECD (2018), states that, "Productivity is not everything, but in the long run it is almost everything. A country's ability to improve its standard of living over time depends almost entirely on its ability to raise its output per worker". This goes to show the critical nature of productivity growth. The basic essence of productivity in industries, organizations and even up to the national and global strata, which has the capacity to drive industrial development on a sustainable basis, is productivity growth or expansion. The phenomenon of productivity growth is so fundamental and vital because providing more goods and services to consumers translates to higher profits; and more profits and investments in the industries on a steady and continuous basis guarantee industrial (organizational) development.

Productivity growth is the essence of all economic life. Organizations and nations spend billions yearly to improve employees who will bring about improvement in productivity (Akanwa and Ohiri, 2003). The quest and search for productivity growth can be traced back to the time of Fredrick Taylor. Taylor and some other authorities had been concerned with the issue of increasing production, and factories and mills through the application of time - and - motion studies long before the social scientists turned their attention to the problems of the environment. Taylor was the first to call attention of people to the quest for improvement in production as an important factor in the work situation (Kennedy, 2016). This marked the advent of Taylorism: production efficiency methodology that breaks every action, job, or task into small and simple segments, which can be easily analyzed and taught (Business Dictionary, 2020). The discovery that individual capabilities differ and that there are low, moderate and high producers (employers), there was need, particularly with the emergence of Industrial Revolution, to seek to improve human productivity to complement machine power and boost production (Zimmich, 2016).

The realization of the importance and relevance of the human factor in not only the production processes but also in the sustenance of productivity growth has been evident right from the early $20^{\text {th }}$ Century, particularly from the point of view of Fredrick Taylor. Individuals constitute the employees in industries and every industry strives to survive, grow and develop because failure to do that ensures their collapse and extinction. Right from the early $20^{\text {th }}$ century to the present $21^{\text {st }}$ century, human beings (workers) remain the most potent factor of production; being the major drivers of the process of production. They make effective and efficient use and management of both fellow human beings (co-workers) and other factors of production such as capital, machine, land, etc., to ensure that production takes place. They also pursue and sustain productivity growth in industries, organizations and nations. The conditions of these workers, that is, employees in terms of their state of mind vis-à-vis confidence, loyalty, commitment, self-esteem, spirit, esprit de corps and determination towards work (put simply, morale) affects what they do and how they do things in the workplace. The role employee morale plays in the pursuit of growth in productivity cannot ever be diminished nor misplaced, particularly, in this $21^{\text {st }}$ century economic context, in which the commitment and hard work of every employee remains significant. If morale is the amount of confidence felt by a person or group of people, especially when in a dangerous or difficult situation, it therefore, expresses the level of satisfaction felt by employees when working together. High morale helps teamwork and information-sharing (Cambridge Dictionary, 2020). This statement sums up the place of the concept of morale in productivity level of employees in organizations. It invariably expresses the efficacy of morale in influencing employee productivity and organizational growth in a struggling economy and growth in productivity of industries in Nigeria. High morale propagates increased teamwork, cooperation and information-sharing. Consequently, it effectively enhances productivity, which in turn, supports sustainable industrial development.

\subsection{Contemporary Challenges of Productivity in Nigeria}

It has been stated and statistically proven that no economy can be more sophisticated than its existing workforce. The quantity and quality of labour, to a large extent, influence and define the profile of any economy (Iheriohanma, 2006; Popoola, 2005). In as much as there have been arguments that labour has made some significant impacts on Nigeria's economy, there are also firm arguments that labour's productivity has been in comatose (Obi et al, 2014). Consequently, Yusuf (2000) opines that productivity, particularly labour productivity has remained abysmally low in the Nigerian economy. Yusuf argues that labour is not the only factor that appears important in industrial productivity but that technical and organizational factors such as power, supervision and equipment, factory layout and system of distribution and coordination of work, may be equally or at times even more important.

Iheriohanma (2006), citing Okojie (1995), Moses (2002) and Popoola (2005), states that some critical factors influence the level of productivity in Nigeria, especially in the public sector. These articulated factors include:

(a) The relatively low skill and industrial experience of Nigerian workers;

(b) System of wages and salary payment and character of incentives schemes;

(c) Adequacy and quality of supervision, management and leadership styles, communication and authority structure;

(d) Conflicting relationship between the tripartite groups in the productive enterprises (the government, management and labour);

(e) Poor motivation packages, reward systems, promotional factors, discipline and implementation of retirement schemes; 
(f) Existence, degree and extent of job security of the employees;

(g) Hygiene factors such as factory design and layout relating to environmental and physical factors;

(h) Socio-economic factors such as increased family commitment and income levels of employees.

(i) Poor national economic policies;

(j) Relative decline in the effectiveness of infrastructures such as education, health, energy, communication, transportation;

(k) Defective and truncated national (economic) planning;

(l) Corruption and decline in national moral standards that dislocate values;

(m) Political instability that truncates all policies, especially in the industrial sector;

(n) Lack of good governance and accountability at the national level;

(o) Culture of materialism that drives most employees to exhibit inappropriate work behaviour in the quest for wealth and maintenance of livelihood;

(p) Structurally induced poverty that has ravaged the entire political and cultural systems;

(q) Defective economic reforms that do not prioritize goals; and,

(r) Centralized management systems, which are constraining bureaucratic regulation and process that stifle initiative and individual control with regard to quick response to efficiency and productivity.

Added to the above include, among others:

i. Poor educational programmes that do not inculcate in the recipients the appropriate functional skills requisite and comparable for working in global organizations that are witnessing new work trends such as work life balance, flexible work arrangements, telecommuting, teleconferencing, compressed work week, employer- and employee-driven work arrangements, outsourcing etc. (Austin-Egole, Iheriohanma and Nwokorie, 2020).

ii. New technological revolution that have continually brought new ways of working and workplace organizations.

iii. Insecurity and uncertainty resulting from poor security architecture in the country; this also threatens human security, workers' job security, commitment and morale.

iv. Downsizing, rightsizing and optimum carrying capacity policies of government and organizations in both public and private sectors of the economy; this threatens job security as it creates environment of uncertainty.

All these factors are critical issues influencing the level of productivity of work organizations, particularly the public sector because they primarily affect the status of employee morale and efficiency. From the relatively low skill and industrial experience of most Nigerian workers ranging from issues of wages/salary payment, incentives schemes, quality of supervision/management and leadership style, conflicting relationship between government, management and labour, poor motivation packages, reward systems up to poor manpower development/utilization policy and bureaucratic bottlenecks that stifle individual initiatives/ control towards efficiency and productivity, employee morale is adversely affected. Each of these factors can be seen to have real and direct impact on the welfare, well-being and emotional stability of employees in one way or the other, and therefore impacts on their morale significantly. For any meaningful productivity growth to occur in the work organizations, particularly in the industrial sector in Nigeria, employee morale has to be made to be at the optimal level. A situation where employers, heads of government establishments etc. see payment of workers' salaries as a gift instead of statutory obligations that should be of first charge does not encourage workers' morale, and by extension, efficiency and productivity.

\subsection{The Concept and Phenomenon of Industrial Development}

Understanding the concept of industrial development entails the comprehension of the process of industrial growth, because industrial growth is an aspect of industrial development. One cannot conceptualize industrial development without first invoking industrial growth. Growth, in simple terms invokes the idea of increase in size, number, value or strength. It connotes enlargement, increment, expansion, maturity, and development (Oxford English Dictionary, 2020). Literally, industrial growth implies increase, expansion or maturity of the industry. Through maturity, the industry stabilizes in strength, processes and development.

Development is a multidimensional process involving many indicators (Chambers, 2004). It revolves around "change" - a social change that predisposes a people to realize their human potentials, "economic growth" that encompasses the need and means to provide better lives for people in poor countries, and "human development" relating to the provision of health, nutrition, education and a clean environment (www.fao.org/docs/up/easypol/882/defining_development paradigms 102en.pdf). Industrial development is a phenomenon with impactful structural meanings and implications for organizations and nations, particularly developing nations such as Nigeria and other African countries. Industrial development is the building and growing of industries within an economy. Industries engage in mass production, technological advances and other services. When an area or economy is industrialized, it experiences an increase in standard of living, job growth, and more 
productivity as it sustains growth. As productivity in an area increases, there is so much more opportunity (EM Founders Group, 2018).

Industrial development is a critical process for every economy or nation that is desirous of emerging as a sustainable economy because of its importance in various ramifications such as generation of employment opportunities, encouragement towards advancement and innovation, and the effective utilization of resources. In fact, these socio-economic benefits are elements that nations leverage on to effect solid national development. Industrial development is therefore, fundamental for developing economies, including Nigeria. Chete, John and Adeyinka (2014) comprehensively defined industrial development as a deliberate and sustained application and combination of suitable technology, management techniques, and other resources to move an economy from a traditional low level of production to a more efficient system of production. Industrial development is one of the best training grounds for skill development, and it can increase the flexibility of the economy and reduce dependence on external forces. Industrial development provides employment, foreign exchange, and domestic earnings. This definition not only captures the strategic essence of industrial development but also its basic national benefits to any country. Industrial development provides economic growth which over time can transform an economy. The twin concepts of industrial growth and economic growth go together because economies thrive when industries within them are growing or expanding. In reality, growth in the industry implies more jobs, more money and more socio-economic opportunities (Imhonopi and Urim, 2014). Also, EM Founders Group (2018) affirms that "industrial growth is often linked with higher wages. The production that industries provide brings more money and more services for the economy, leading to higher income per capita and more labour productivity. The standard of living increases when industry increases. These opportunities can transform an area and inspire endless amounts of growth". By extension, economy blossoms to the benefits of all and eliminates the negative consequences and indices of poor economy.

From a more practical perspective, industrial development is the synthesis of contributions from four major factors, namely: business, technology, government and labour; and, successful industrial projects can be achieved only through a close co-operation and mutual understanding between these contributors. Industrialization or the action of developing industries on a large scale, generally at national level, has a great importance for the economic growth of the country with positive results in creating wealth and employment with the attendant social improvement effects (Fliss, 1997). In furtherance, Fliss identified four major factors that contribute to industrial development in any country, their contributions and motivations are identified in Table 1.

Table 1: Major Factors Contributing to Industrial Development

\begin{tabular}{|l|c|c|}
\hline \multicolumn{1}{|c|}{ Contributors } & Contribution & Motivation \\
\hline Investors & Capital & Profit \\
\hline Developers & Technology & Profit and Reputation \\
\hline Local Population & Labour & Employment, Welfare \\
\hline Government & Infrastructure, Natural Resources, Legislation & Taxation \\
\hline
\end{tabular}

Source: Fliss (1997). The Engineering of Industrial Developments, Romanian Academy (5 ${ }^{\text {th }}$ ed.). Timisoara.

In continuation, Fliss posits that this is a rather simplistic description of the industrial development scenario, because contributors may play more than one role and they may have additional contributions and motivations, for example, the investor may be at the same time his own developer or government may become also an investor. Again, he identified three categories of industrial development with each having its own specific character concerning the financial, managerial, technical and labour matters, and they are:

1 Grassroots

- when the development is taking place from an under-developed site

$2 \quad$ Brown Field

$3 \quad$ Red Field

- expanding on existing industrial sites

- revamping production facilities under operational conditions (Fliss, 1997).

All these categories or stages of industrial development are manifest in the state of Nigeria's industrial experiment and development. Many unutilized/underutilized natural resources and underdeveloped sites exist across the Nigerian industrial landscape. As a developing economy, Nigeria has not been at its best in the area of expanding on existing industrial sites but there are some emerging industrial sites with potentials for greater prospects. From the point of view of the red field as enunciated above, Nigeria needs to do extensive work in order to come to terms with the contemporary industrial challenges of the nation. Many moribund industries and organizations are in urgent need of resuscitation or fresh build-up because of years of neglect and deterioration. Some of these projects/industries include the Ajaokuta Steel Mills, Mambila Plateau Power Projects, oil refineries, etc. In fact, the national industrial outlook shows the concentration of some level of industrial development in a few metropolis/business centers such as Lagos, Abuja, Ibadan, Jos, Kaduna, Kano, Nnewi, Aba, Port-Harcourt, while most of the other parts of the country including areas with significant deposits of natural resources remain unexploited with little or no industrial presence. Concentration has remained on oil resource that has tied the country to a mono economy since the 1970 s to the detriment of economic diversification. No one has ventured 
into the grassroots and red-fields areas and critical sectors of the economy in Nigeria. This is partly where Nigeria's industrial development crisis lies. This calls for immediate and swift action from the principal contributors in the industrial development process that includes investors, developers, labour and governments. In essence, industrial development is a positive phenomenon that entails the application of technology and science in fostering a country's capacity to transform raw materials into finished goods and services for individual/societal consumption and sustainable development.

\section{Employee Morale, Productivity and Sustainable Industrial Development in Nigeria: An Analysis}

Morale, in practical terms as a state of mind, has been established as a human factor and force to reckon with in human productivity. Morale of workers in any organization reflects in the overall productivity of that organization. Evidence from numerous literature and statistics echo a common theme: employee input is crucial to high morale. Employee morale refers to the emotions, attitude, satisfaction, and overall outlook of employees during their time in a workplace environment. Part of effective productivity is thought to be directly related to the morale of the employees. Employees that are happy and positive at work are said to have positive and high morale. Companies that maintain employees who are dissatisfied and negative about their work environment are said to have negative or low employee morale (Business Dictionary, 2020). Consequently therefore, it behooves on organizations to constantly endeavor to keep employee morale high so that they can get the best from their workers. Among the many ways of positive management of employee morale is the use of incentives in work environment which is an outstanding and effective way to enhance employee morale because it has the potentials to make employees feel more appreciated and to have a connected sense of belonging which can propel them to work more efficiently and happily. Core (2015) observes that, "most productive companies have happy and healthy employees, which are the basis of a successful organization". The importance of employee morale to organizational productivity and growth is not in doubt considering the obvious fact that human beings as a factor of production actually manipulate and control all other factors of production and therefore their state of mind, attitude to work and work habits reflect on the level of productivity. This makes good employee morale instrumental for improving productivity in an organization or economy.

Employee morale can be an enormous factor in the pursuit of corporate/organizational success in the area of efficiency, effectiveness, commitment and profitability. Poor morale is the primary driver that breeds dissension, turnover, espionage and inefficiency. Knowledge management and organizations crave for consistent morale strategy as this avails them the opportunity to detect symptoms that cause poor morale.

As company develop and evolve, various internal and external stimuli can introduce morale problems into any team (Rismedia, 2008). Maintaining good employee morale requires the adoption of certain actions to show employees that things do change for the better, particularly when the lines of communication are open and welcoming. Making efforts to open communication indicates receptiveness to change, provides career advancement, treating employees fairly, building workforce's confidence and commitment towards the organization. In line with the importance of managing employee morale in organizations, Mcfarlin (2020), enunciated a number of measures that can help organizations to maintain good/high employee morale for organizational growth and they include: public appreciation of good performance and acts of integrity, conducive work environment, clear-cut job description such that employees know the exact duties and responsibilities/tasks expected of them, provision of surprise packages which enliven and motivate employees, ensuring that every employee has a sense of belonging and feel they are part of a team, and termination or transfer of employees who influence others negatively.

Employee morale as the all-round viewpoint of people in the workplace indicates the perception of organizational policies, emotions, attitude, outlook and the employees' level of commitment and satisfaction. It overruns the outcome of conditions of work and work attitudes and habits and not the cause. Positive morale among employees generates confident, devoted and satisfied employees, while poor morale can be seen in antagonistic, uncooperative and less concerned employees who are often found lacking in terms of efficiency and productivity as well as safe business practices. In practice, good or bad morale can influence a number of areas in an organization such as employee attitude to work, productivity, decision-making, workplace safety, relationships with co-workers and management, punctuality and attendance including general attitude within the work environment (Jike, 2003). Relying on the conceptual meaning of morale, according to Cambridge Dictionary (2020), as the amount of confidence felt by a person or group of people, especially when in a dangerous or difficult situation, it implies that it is a significant factor that affects and influences employees and their efficiency and output at work, especially in trying to grow and develop an ailing economy. Ransom (1995) states that, "the morale of a business allows it to accomplish more than its cumulative talents would suggest. It operates in a synergistic mode using management, employee and customer participation to resolve its problems". In furtherance, Ransom lists three features of an organization with high morale:

1 Gives workers the freedom and autonomy to do their jobs;

2 Rewards the employees for exceeding expectations, 
3 Listens to employees, and swiftly acts to resolve any disputes.

Nigeria, as a struggling and developing economy with poor productivity levels, therefore needs to work on employee morale as an imperative not only for organizational growth and development but also for national and sustainable development.

Many organizations have attributed their success largely to the input from the employees into the decisionmaking process. But with the myriad of issues challenging the productivity of work organizations in Nigeria resulting from the conditions of the work environment which adversely affect workers, there is a compelling need to reinvigorate the morale that is often at low ebb. Studies such as that of Elton Mayo evidently portray the significant place and influence of employee morale in the workplace. Elton Mayo ran a series of experiments from 1927 to 1932 to determine how changing the physical environment would impact production. These tests were dealt primarily with the lighting of the work area at Western Electric's Chicago Hawthorne Plant. In a certain control group, the test subjects continue to produce consistently even when the lighting was reduced to near darkness. This simple control group knew they were being tested. It was later determined that the morale and motivation of the consistently productive control group was their impetus for production; and this gave birth to the "Hawthorne Effect" (Fry, 1989).

It is equally on records that other public administration authorities concur with the findings of the Hawthorne experiment. In the textbook, "Organizational Theory": A Public Perspective", the authors, (Gotner, Mahler and Belle, 1997), also concluded that the significance of the Hawthorne effect was not the lighting or lack thereof, subjected to the test subjects. These authorities concluded the following: the most important factor influencing the workers was not the physical environment, but the attitudes that resulted from the workers seeing themselves as important to the on-going experiment (Gotner et al., 1997). In consonance, Neely (1999) postulates that many literature indicated that there is a by-product of employee input and morale and it translates into a more productive workforce. These literature reviews only served to further solidify Neely's hypothesis that an increase in the independent variable $\mathrm{x}$ (morale), would provide a commensurate increase in the dependent variable Y (employee productivity).

The nexus between employee morale and productivity has a lot of implications for industrial growth and therefore constitutes a critical synergy for the pursuit of industrial development and by extension, sustainable industrial development in Africa and particularly in Nigeria. Improving productivity performance is critical for rapid industrialization and economic growth in any economy. Several policy measures in Nigeria have emphasized improving productivity and performance. The adoption of the economic reform programmes is necessitated by the move towards a market economy.

Productivity and performance are hardly realizable if employee morale is stifled either at conception or in the process of organizational management. Productivity as the quantum of performance is an outcome of the benefits of improved employee morale. While morale lifts productivity from the ebbs, it is the energizing nucleus or ' $k p i m$ ' of performance indicator that mid-wives productivity. This synergy is articulated on the premise that employee morale is a sine qua non to productivity and performance and by extension, industrial organizational growth and sustainable development.

The reforms and synergic relationship analysis above explicitly emphasize the need to improve the competitive and comparative performance of industries. Nevertheless, the question remains: have policy efforts and programmes targeted at improving industrial productivity in Nigeria yielded significant results? (Chete et al, 2014). The prevailing challenges of productivity in work organizations, particularly the public sector in Nigeria militate against the affirmative response to the above question. In real terms, all the problems associated with the low productivity of most organizations in Nigeria are fundamental issues that undermine employee morale and the development of positive and result-oriented work attitudes. The quest for sustainable economic development in Nigeria has made it imperative for the operators of the economy, and especially the management of the productive, manufacturing and the public sector of the economy to jettison those forces that would derail the march towards industrialization, industrial development and productivity. Nigeria, like most other African countries, is a developing economy, and therefore industrial development should be an imperative. Nigeria is inherently endowed with assets and resources. The need for Africa to industrialize was reflected in a resolution by the UN General Assembly, which highlighted that the continent has "to advance sustainable industrialization as a key element of furthering economic diversification and value addition, creating jobs, and thus reducing poverty and contributing to the implementation of the 2030 Agenda for Sustainable Development (UN General Assembly, 2016).

According to UNIDO (2016), "the time is ripe for Africa to industrialize. In fact, industrialization is key if we are to achieve the Sustainable Development Goals by 2030, in particular SDG-9-Build Resilient Infrastructure, Promote Inclusive and Sustainable Industrialization and Foster Innovation”. The UNIDO (2016) report on Africa and Sustainable Development Goals states that industrialization does not happen automatically. Africa needs to build on its existing economic structures, engage in trade and regional integration, and access newly available technologies, and ensure the social and economic inclusion of women and the young. From the action and process of building on existing economic structures up to accessing new technologies and adopting socio-economic 
inclusion of women, young people and the vulnerable involves partly and significantly the issue of morale of the majority of the productive workforce in the country. The relevance of employee morale in the sustenance of productivity growth is not in doubt given the unlimited positive impacts employee morale has effected in many work organizations in the developed nations across the globe (Egwuonu, 2015). Nigeria needs to come all out with her endowments and political will to pursue and ensure the realization of concrete industrialization built on inclusiveness in order to reawaken her drive towards economic greatness.

However, for industrialization to take place in a sustainable manner in any economy, including Nigeria, the basic need for employee morale which effectively improves productivity should equally be kept high in a sustainable way. Importantly, employee morale is partly and influentially instrumental to generating increased productivity which in turn propels economic growth. On the other hand, economic growth is said to be a phenomenon that goes hand-in-gloves with industrial growth, which on a sustained basis brings industrial development. Kniivila (2006) emphatically states that "industrial development has had an important role in the economic growth of countries like China, The Republic of Korea (Korea), Taiwan Province of China (Taiwan) and Indonesia. Along with accelerated growth, poverty rates have declined in many countries. Some countries have managed to achieve equity whereas in others inequality has remained high". Nigeria with its profound patriarchal structures has a poor scorecard in terms of socio-economic inequalities and gender discrimination and these constitute significant obstacles towards achieving sustainable development in different facets of the UN programme. Such inequalities act as impediment to any form of inclusive agenda, including the U.N. Sustainable Development Goals.

As Nigeria forges ahead towards 2030 - the deadline for achieving these goals, it is of utmost importance for the nation to embrace every possible measure that can facilitate its efforts to succeed in the realization of the SDGs. Central to this pursuit, is the attainment of sustainable industrial development. Coming from years of sluggish, poor/low industrialization, with a foundational weak economy and issues of poor leadership, corruption, insecurity, and dilapidated development infrastructure, the necessary level of stability for pursuing these goals may seem farfetched. It is therefore, extremely important that productivity, which is the lifeline of any economy, is strengthened in order to help and power the drive for achieving economic growth and sustainable development, particularly in the realm of industrial advancement. Notably, Industrial Development Report (2018) explicates that inclusiveness and sustainable industrialization is foundationally essential to realizing sustainable development. It unleashes dynamic and competitive economic forces that generate and propel employment and income, facilitates international trade and sustains efficient use of resources. Consequently, it is a major driver and facilitator of poverty alleviation and shared prosperity.

More fundamentally, where new industries are created in underdeveloped areas, new settlements are built to accommodate industrial personnel and entrepreneurs are attracted by opportunities to serve the new industries and their relatively high income people. The positive effect of industrial development may expand even further as it may encourage development of general infrastructure of the area such as transportation, water and power supply, which in turn may attract development of other sectors of the economy. We can see that in addition to being a provider of growth and employment on its own interest, industrialization generally has catalytic effects on many other socio-economic aspects of a region or of the whole country (Fliss, 1997). Against this backdrop, the exigency for Nigeria's industrial development, particularly on a sustainable basis cannot be understated. In this pursuit, productivity growth is almost inevitable and high employee morale being one of its major drivers must be upgraded and sustained in work organizations, particularly in industries in Nigeria. This agenda of managing and improving the level of employee morale is a prerequisite for powering national productivity in Nigeria in the $21^{\text {st }}$ century competitive and turbulent global economy. High morale incubates and acts as a springboard to increased teamwork, cooperation and information-sharing. Consequently, it effectively enhances productivity and performance which in turn, supports sustainable industrial development. Nigeria has the onerous but achievable task to work on the philosophy of employee morale, organizationally and nationally, in order to derive its quantum benefits on productivity for the attainment of sustainable industrial development in the country.

\section{Conclusion and Recommendations \\ 4.1Conclusion}

The three concepts of morale, productivity and industrial development are related in structural context and in real terms. Their interface and working relationships in industrial organizations can be observed in practical terms. Morale is a general human concept that affects employees in every organization or human endeavour in terms of work attitudes, work habits and productivity. Because high morale in the workplace is critical to organizational productivity and success, it has direct consequences on industrial development in an economy, including Nigeria's. The level of industrial development in Nigeria can be said to be a reflection of the nation's productivity and by extension the status of employee morale.

Part of the contributory factors to the rising corruption in the public sector and the nation as a whole has been attributed to the issue of low morale occasioned by the foreseen inconstant payment of salary, gratuity and pension. 
Some workers engage in all manner of illicit acts and unprofessional conducts to enrich themselves because they are owed salaries for uncountable months. Same applies to retired civil servants. Akedi (2013), Onyema (2012) and Njoku (2018) various observe that official corruption and disengagement lethargy have found their roots in the structural ill-fated foundations in the workplace organizations, especially in the public service in Nigeria that do not encourage morale, commitment, efficiency and productivity. Conclusively, morale is a critical foundation to performance and efficiency which in the main create structures and impetus to productivity. A productivity economy is a reflection of the country's critical and efficient demographic labour population and the economy's level of growth which when stabilized and concretized generates spring board for sustainable industrial development.

\subsection{Recommendations}

In her pursuit for sustainable industrial development, Nigeria can start from the point of improving on the state of employee morale by implementing the following recommendations.

- Part of Nigeria's strategic efforts to achieving sustainable development should include sustenance of positive employee morale in the workplace because it is critical to attaining better productivity, lower employee turnover, good work attitudes and habits, safe business practices and fewer workplace - related injuries and accidents as well as improved employee relationships. In line with this, the major stakeholders in industrial organizational development process in Nigeria, that is, investors, developers and particularly governments must exploit all available and practicable measures aimed at improving and maintaining positive/high employee morale for increased productivity.

- The governments at all levels must as part of their "Ease of Doing Business" policy, develop effective programmes through relevant agencies such as National Orientation Agency (NOA) and others to prioritize employee morale with a view to positively reinventing the state of employee morale in the Nigeria industrial sector.

- The challenge of poor power supply, lack of access to soft loans, some unfavorable government fiscal policies, and some other prevailing factors affecting the productivity of small and medium scale enterprises should be mitigated and or taken care of. These issues primarily affect the small businesses and their workers in many adverse ways, including their morale because working under these conditions can be stressful and less profitable.

- To counter the scourge of low morale among public servants resulting from none payment of salaries and retirement benefits, the federal and state governments have the responsibility and obligation to not only ensure regular payment of salary but also generally improve on staff welfare and corporate management. Payment of salary and other entitlements serve as basic incentives that motivate workers and consequently boost employee morale. A worker deserves his wages. The payment of salaries and retirement benefits should not be seen by political leaders as favours granted to workers as this act is demoralizing. It is a statutory responsibility by political office holders. Corruption that has hit the progress of organizations and the services should be reduced and at most eliminated. Discriminatory policies on salary structures and payments should be decried and jettisoned through legal framework.

- It is equally of importance that the conflicting relationship between governments and various workers' unions, particularly Nigerian Labour Congress (NLC), Academic Staff Union of Universities (ASUU), Academic Staff Union of Polytechnics (ASUP), National Union of Petroleum and Natural Gas (NUPENG), Joint Health Services Union (JOHESU) and other such unions in the country are managed more positively to ensure that workers interests and welfare are incorporated as part of the strategic efforts towards facilitating the realization of sustainable industrial development in Nigeria. This is because the unions work for the good of their members who constitute part of the national workforce. Therefore, the stability and progress of the unions also help, to a large extent, to impact positively on employee morale, job security and productivity.

- The National Assembly should enact new laws that can help to engender better relationship amongst the tripartite members in industrial relations. These measures are imperatives for attaining enviable productivity and sustainable industrial development in Nigeria.

- Sustainable industrial development is stable where there is inclusiveness in labour matters and employment for all to contribute meaningfully to the growth. Efforts should therefore, be made to facilitate job creation and conducive workplace environment to encourage industrial growth and development in Nigeria.

\section{References}

Akanwa, P.U. and Ohiri, A.U. (2003). Principles of Management and Human Relations. Owerri. Global Press Ltd. Akedi, T.U. (2013). Development and Women Productivity in $21^{\text {st }}$ Century Nigeria. Lagos: Stone Books.

Belson, K. (2012). Morale, New York Times, 2012 November 2. 
Business Dictionary (2020). "Definition of Taylorism”. www.businessdictionary.com

Cambridge Dictionary (2020). "Definition of Morale". http://dictionary.cambridge.org

Chambers, R. (2004). Ideas for Development, IDS Working Paper238. Sussex: IDS.

Chete, L.N., John, O.A. and Adeyinka, F.M. (2014) "Industrial Development and Growth in Nigeria: Lessons and Challenges". WIDER Working paper 2014/019. Helsinki:UNU-WIDER.

Collins English Dictionary (2018). "Definition of Morale". https://www.collinsdictionary.com

Egwuonu, U. (2015). Growth, Development and Sustainable Development. Umuahia: Peace Press.

EM Founders Groups (2018). "Why is Industrial Development Important". www.eaglemountainutah.com

Fliss, L. (1997). The Engineering of Industrial Developments, Romanian Academy. (5 ${ }^{\text {th }}$ ed.). Timisoara.

Fry, B. (1989). Mastering Public Administration, Chatham: N.J. Chattam House Publishers Inc.

Gamelearn (2020). "Time Management and Productivity: What is Productivity". www.game-learn.com

Gotner, H., Mahler, J. and Belle, N. (1997). Organizational Theory: A Public Perspective. (2 ${ }^{\text {nd }}$. ed). Belmont. CA.: Wadworth Publishing.

Hulten, C.R. (2009). “Growth Accounting” (PDF). National Bureau of Economic Research Doi:10.3386/W 15341.

Iheriohanma, E.B.J. (2006). The Challenging Problems of Productivity in Nigeria Public Institutions: Issues and Strategies. Nigerian Public Administration Review 1 (1): 116-125.

Imhonopi, D. and Urim, U.M. (2014). Industrial Development in Nigeria: Achieving Brass Tasks. In D. Imhonopi \& U.M. Urim (Eds.), Trajectory to Industrial Development in Nigeria. Pp 2-12. Lagos: Department of Sociology, Covenant University, Ogun State.

Industrial Development Report (2018). Demand for Manufacturing: Driving Inclusive and Sustainable Industrial Development. United Nations Industrial Development Organization (UNIDO).

Jike, V.T. (2003). Organizational Behaviour and Negative Attitude in Nigeria's Public Employment Sector: The Empirical Nexus. Abuja Management Review. 1 (4) 34 - 45

Kennedy, T. 2016). Productivity in the Context of Globalization. Accra. Lightwood Publishers.

Knickerbocker, H.R. (1941). Is Tomorrow Hitler's? 200 Questions on the Battle of Mankind. Reynal \& Hitchcock. P. 96.

Kniivila, M. (2006). Industrial Development and Economic Growth: Implication for Poverty Reduction and Income Inequality. The United Nations. https://www.un.org>publications.

Krugman, P. (1994). "Defining and Measuring Productivity". In OECD Report (2016). https://www.oecd.org >sdd > produ...

Leighton, A.H. (1949). Human Relations in a Changing World: Observations on the Uses of the Social Sciences. New York: McGraw-Hill Inc.

Longman Dictionary of Contemporary English (2020). https://www.idoceonline.com

Mali, P. (1978). Improving Total Productivity. New York: John Wiley and Sons.

McFarlin, K. (2020). "How to Promote Good Morale in the Workplace", smallbusiness.chron.com/prom...

Metrics (2016). "Metrics: Four Types of Productivity" Software Process and Measurement. www.tcagley.wordpress.com

Neely, G.H. (1999). “The Relationship between Employee Morale and Employee Productivity”. An Applied Research Project Submitted to the National Fire Academy as Part of The Executive Fire Officer Program, July, 1999. PDF en.m.wikipedia. org/wiki/morale.

Njoku, K. C. (2018). Disengagement Lethargy and Productivity among Public Servants in Imo State, Nigeria. Ph.D Dissertation, Imo State University, Nigeria.

Nwachukwu, C.C. (1988). Management: Theory and Practice. Onitsha: Africana-FEP Publishers Ltd.

Nwokocha, I. (2014). Sustainable Managerial Strategies for Employee Retention in Two Private Sector Organizations in Port Harcourt, Rivers State, Nigeria. Doctor of Philosophy (Ph.D) Dissertation. Ebonyi State University, Abakaliki, Ebonyi State, Nigeria.

Ogunde, P. (2013). Nigeria Civil Service and National Development. Ibadan: Bricks Publishers.

Onosede, G. (2013). Government Policy and Industrialization in Nigeria: Some Contemporary Issues for National Development. Lagos: Skylevel Publishers.

Onyema, A.C. (2012). Management of Gender Issues in Public Service in Nigeria. Umuahia Evergreen Publishers.

Organization of Economic Cooperation and Development (OECD) Report (2018). https://www.oecd.org $>$ sdd $>$ produ...

Oxford Dictionary (2020). "Definition of Morale". https://www.lexico.com

Oxford English Dictionary. http://oxforddictionaries.com

Ransom, W. (1995). "Building Employee Morale”. Daily Reporter (September, 1995).

Robbins, T. (2018). "How to Improve Productivity - and Why You Should". Posted by Team Tony. www.tonyrobbins.com

Standard Encyclopedic Dictionary (1971). "Definition of Morale”. Chicago: JG Ferguson Publishing Company

Ulio, J. (1941). "Military Morale”. American Journal of Sociology, 47(3) Nov., 1941. 
United Nations General Assembly (2016). $71^{\text {st }}$ Ordinary Session Report. https://www.un.org

United Nations Industrial Development Organization Annual Report (2016). https://www.unido.or>publication Yong, L. (2016). “Accelerating Industrial Development in Africa. UNIDO Report. africapolicyreview.com Yusuf, T.M. (2000). The human factor in national development in Nigeria. Ibadan: Spectrum Books Limited. Zimmich, M. (2016). The birth of industrial relations. New Delhi. Oriental Press. 